\title{
Agronomic performance of onion hybrids in Baraúna, in the semi-arid region of Brazil ${ }^{1}$
}

\author{
Desempenho agronômico de híbridos de cebola na região semiárida em Baraúna-RN
}

\author{
Renato Leandro Costa Nunes ${ }^{2 *}$, Alexandre Bosco de Oliveira ${ }^{3}$ e Alek Sandro Dutra ${ }^{3}$
}

\begin{abstract}
In the Brazilian state of Rio Grande do Norte, the significant planting of onions is relatively recent, with producers seeking alternative ways to reduce losses. As a result, it was aimed to evaluate the agronomic performance of onion hybrids in the town of Baraúna in the semi-arid region of Rio Grande do Norte. The experimental design was of randomised blocks with six replications. Treatments consisted of eight hybrids (Cronus F1, Predilata F1, Serena F1, Fortaleza F1, Mata Hari, Luana, Lambada, Don Victor) and a control cultivar (IPA 11). The following were evaluated: average plant height; average number of leaves; diameter of the pseudostem; productivity; average bulb weight; rate of survival; leaf-waxiness; cultivar cycle; commercial classification of the bulbs. The Serena F1 and Mata Hari cultivars are recommended for the northeast semi-arid region due to high productivity, early cycle and better bulb classification. The use of these cultivars may help, in the short term, to change cultivation of the onion in the state of Rio Grande do Norte.
\end{abstract}

Key words: Allium cepa. Productivity. Precocity. Bulb classification.

RESUMO - No estado do Rio Grande do Norte o plantio de cebola de forma mais expressiva é relativamente recente, sendo que produtores então buscando alternativas como formas de diminuir os prejuízos. Em função disso, objetivouse avaliar o desempenho agronômico de híbridos de cebola na região semiárida no município de Baraúna - RN. O delineamento experimental foi o de blocos casualizados com seis repetições. Os tratamentos consistiram de oito híbridos (Cronus F1, Predileta F1, Serena F1, Fortaleza F1, Mata Hari, Luana, Lambada, Don Victor) e uma cultivar testemunha (IPA 11). Foi avaliada a altura média de plantas, o número médio de folhas, o diâmetro do pseudocaule, a produtividade, a massa média dos bulbos, o índice de sobrevivência, a cerosidade foliar, o ciclo das cultivares e a classificação comercial de bulbos. As cultivares Serena F1 e Mata Hari são recomendadas para a região semiárida nordestina em função da alta produtividade, ciclo precoce e melhor classificação dos bulbos. O emprego dessas cultivares poderá, em curto prazo, contribuir para mudar o panorama da cultura da cebola no Estado do Rio Grande do Norte.

Palavras-chave: Cebola. Produtividade. Precocidade. Classificação dos bulbos.

\footnotetext{
*Autor para correspondência

${ }^{1}$ Recebido para publicação em 25/06/2013; aprovado em 30/03/2014

Pesquisa financiada pela Empresa Frutas Novo Horizonte Ltda

${ }^{2}$ Programa de Pós-Graduação em Fitotecnia, Departamento de Fitotecnia, Universidade Federal do Ceará, Fortaleza-CE, Brasil, renatoleandro. ce@ hotmail.com

${ }^{3}$ Departamento de Fitotecnia, Universidade Federal do Ceará, Campus do Pici, Blocos 805, Fortaleza-CE, Brasil, 60.356-000, alexandrebosco@ ufc.br, alekdutra@ufc.br
} 


\section{INTRODUCTION}

In Brazil, the onion (Allium cepa L.) ranks third in economic importance, with an average productivity of $17.88 \mathrm{tha}^{-1}$. The northeast region, due to edaphoclimatic conditions, offers many advantages compared to other onion producing regions of the country, since it allows year-round planting (GRANGEIRO et al., 2008). More than half the domestic production is concentrated in family farms of less than 20 hectares (VILELA et al., 2005), and is of great socioeconomic importance in the Brazilian productive chain.

According to the United Nations Food and Agriculture Organisation: Food and Agriculture Organization (2010), global onion production in 2010 was 78.53 million tonnes. The seven largest producers are China, India, the United States, Egypt, Iran, Turkey and Brazil. Together these countries produced $61 \%$ of the world production. Brazil produced 1.75 million tonnes, which represents around $2 \%$ of world production, and is the seventh largest producer of the vegetable.

According to Faria et al. (2012), the consumption of onions in Brazil in recent years is practically steady at between 750,000 and 850,000 tonnes per year. Of this total, the country has imported between 75,000 and 330,000 tonnes annually, a volume that varies according to the reduction in domestic supply, whether due to adverse climatic conditions or to being less competitive in the market due to the low classification and standardisation of the Brazilian onion.

Production in the northeast stood at 294,232 tonnes, with the states of Pernambuco and Bahia, the largest producers in the northeast, having an average productivity of 106,506 and 187,726 tonnes respectively. In the 2011/2012 harvest, 1.42 million tonnes of onions were produced. According to the Brazilian Institute of Geography and Statistics: Instituto Brasileiro de Geografia e Estatistica (2012), data shows the area under onion production in Brazil for that harvest was 57,620 hectares, $4 \%$ lower than in the previous harvest.

According to Bandeira et al. (2013) the northeast region has seen the expansion of the area under onion production by drip irrigation, a technology that allows high yields and improvements in the quality of the product, when associated with the use of superior genetic material. The choice of onion cultivars should take into account requirements for light, and the temperature and brightness of the regions (LONGO, 2009). If weather conditions do not meet the demands of the crop, there may be losses in production, with reduced bulbing, early issue of the floral tassel, the formation of "cigars" and small bulbs (RESENDE; CHAGAS; PEREIRA, 2003).

However, the use of hybrids in the domestic market is still new, with little information concerning the agronomic response of the hybrids and strains to be used in crossings (FARIA et al., 2012).

In the state of Rio Grande do Norte, significant planting of onions is recent, with growers seeking alternatives as a way of reducing losses. Accordingly, the new use of hybrid cultivars by producers should be highlighted as it consists of one of the most important technologies for increased productivity.

Due to the economic importance of the onion and to the demand for promising cultivars in production regions having a similar ecology, the aim was to evaluate the agronomic performance of onion hybrids in the semi-arid region of the municipality of Baraúna, Rio Grande do Norte.

\section{MATERIAL AND METHODS}

The work was carried out in the municipality of Baraúna, in the semi-arid zone of the state of Rio Grande do Norte (RN). The area under study is part of the Apodi Plateau region, where one of the most prosperous Irrigation Centres in the northeast is located. Geographically, the municipality of Baraúna is limited in the east by the city of Mossoró, to the west and north by the State of Ceará and to the south by the municipality of Governador DixSept Rosado. With an area of $888 \mathrm{~km}^{2}$, it is located in the Mossoró microregion, at 5 $04^{\prime} 44^{\prime \prime} \mathrm{S}$ and $37^{\circ} 37^{\prime} 00^{\prime \prime} \mathrm{W}$ and at an altitude of $94 \mathrm{~m}$. The soil was classified as a Ta Haplic Cambisol Tipic Eutropic with a sandy-loam texture, type A moderate, hyper-xerophilous caatinga stage, flat relief, limestone substrate (EMPRESA BRASILEIRA DE PESQUISA AGROPECUÁRIA, 2006; MOTA, 2004).

The predominate climate in the region according to the Köppen classification is type BSWh', characterised as very hot and semi-arid, with the rainy season going on into the autumn. The rainfall index is on average around 677 mm per year (AMARO FILHO, 1991).

The experimental design was of randomised blocks with six replications. This was set up on plots of $1.0 \mathrm{~m}^{2}$, having a useable area of 10 rows for planting. Treatments consisted of eight hybrids (Cronus F1, Predileta F1, Serena F1, Fortaleza F1, Mata Hari, Luana, Lambada, Don Victor) and one control (IPA 11) respectively.

The onion seedlings were produced in polystyrene trays, each of 200 cells containing the commercial substrate Plantimax. The trays were kept in greenhouses and irrigated by micro sprinkler. The seedlings were transplanted 60 days after sowing, when they had reached a height of around $25 \mathrm{~cm}$ with a pseudostem of 5-6 mm in diameter, as recommended by Vargas, Braz and May (2007). Transplanting was into beds, $1.20 \mathrm{~m}$ wide, $1.0 \mathrm{~m}$ long and $0.25 \mathrm{~m}$ high, made with a rotary hoe. The plots 
were made up of 10 rows, spaced $10 \mathrm{~cm}$ apart, with a space of $4 \mathrm{~cm}$ between plants, giving a total of 250 plants per plot $(1,250,000$ plants per hectare).

At planting, $300 \mathrm{~kg} \mathrm{ha} \mathrm{h}^{-1}$ of NPK 04-14-08 fertilizer was applied by broadcasting in accordance with recommendations for the crop based on soil analysis. As topdressing, $80 \mathrm{~kg} \mathrm{ha}^{-1} \mathrm{~N}$ and $60 \mathrm{~kg} \mathrm{ha}^{-1} \mathrm{~K}_{2} \mathrm{O}$, were applied in two instalments, at 30 and 60 days after transplanting.

Phytosanitary management was carried out when necessary for thrips and anthracnose (Colletotrichum gloeosporioides sp.) by the application of the pesticides, Sumithion 500 EC and Viper 700 respectively, following the recommendations for onion crops. Weeds were controlled by hand weeding. The experiment was irrigated periodically from August to December, depending on the rainfall in the region. The average temperature recorded during collection of the data from August to December was $28.5{ }^{\circ} \mathrm{C}$, with a relative humidity of $62 \%$. The following were evaluated: average plant height; average number of leaves; pseudostem diameter; productivity, average bulb weight; survival rate; leaf waxiness; cultivar cycle; commercial bulb classification.

Average plant height was determined randomly in 50 plants from each plot by measuring the distance in $\mathrm{cm}$ from ground level to the tip of the longest leaf. To determine the average number of leaves, only green leaves were counted, i.e. those photosynthetically active, in order to get the average for 50 plants per plot. The diameter of the pseudostem expresses the degree of bulb development, and was obtained with the use of callipers, by measuring the stem of each plant 100 days after the seedlings had been transplanted to the field.

The correct time for harvesting was set for when $70 \%$ of the plants displayed softening of the pseudostem and falling shoots, based on the proposal of Finger and Casali (2002) of 50-90\%. After harvesting, the bulbs were left in the field for a period of 25 days with no rain, in order to start the curing process; they were then placed in a shed where they were cleaned and allowed to finish curing. The following were then evaluated: total production of the plot, converted into $\mathrm{kg} \mathrm{ha}^{-1}$; average bulb weight; plant survival rate (number of plants harvested in relation to the number planted), with data expressed as a percentage. Leaf waxiness was measured at 100 and 125 days after planting, as the average of the two evaluations. A grading scale was used, ranging from 1 to $5(1=$ no waxiness, 2 = little waxiness, 3 = medium waxiness, $4=$ fairly waxy leaves, 5 = very waxy leaves). The waxy group has leaves of an opaque-green colouration, due to the large wax deposits on the leaf surface. The intermediate group consists of plants with opaque-green leaves, though less intense, due to the reduced presence of waxes on the leaf epidermis. The non-waxy plants are characterised by having bright green leaves, due to the absence of wax. The cycle was expressed in days. Commercial classification was determined by dividing the bulbs into classes depending on the size of their transverse diameter and weighing each class individually. The data were subjected to variance analysis and the averages compared by Skott-Knott test $(\mathrm{p}<0.05)$.

\section{RESULTS AND DISCUSSION}

The Serena F1 and Mata Hari hybrids had plants with height and pseudostem diameter significantly greater than the other cultivars under test $(0.547,0.513$ respectively and 0.022 each) (Table 1). There were significant differences between materials with respect to the

Table 1 - Plant height, number of leaves and pseudostem diameter in nine onion cultivars grown in the semi-arid region in Baraúna, RN, 2012

\begin{tabular}{|c|c|c|c|}
\hline Cultivar & Plant height(m) & Average number of leaves & Pseudostem diameter $(\mathrm{m})$ \\
\hline Cronus F1 & $0.458 \mathrm{~b}$ & $10.04 \mathrm{a}$ & $0.018 \mathrm{~b}$ \\
\hline Predileta F1 & $0.483 \mathrm{~b}$ & $10.32 \mathrm{a}$ & $0.018 \mathrm{~b}$ \\
\hline Serena F1 & $0.547 \mathrm{a}$ & $11.50 \mathrm{a}$ & $0.022 \mathrm{a}$ \\
\hline Fortaleza F1 & $0.468 \mathrm{~b}$ & $10.56 \mathrm{a}$ & $0.019 \mathrm{~b}$ \\
\hline Don Victor & $0.454 \mathrm{~b}$ & $9.89 \mathrm{~b}$ & $0.016 \mathrm{c}$ \\
\hline Luana & $0.427 \mathrm{c}$ & $9.34 \mathrm{~b}$ & $0.017 \mathrm{~b}$ \\
\hline Mata Hari & $0.513 \mathrm{a}$ & $11.02 \mathrm{a}$ & $0.022 \mathrm{a}$ \\
\hline Lambada & $0.497 \mathrm{~b}$ & $10.96 \mathrm{a}$ & $0.018 \mathrm{~b}$ \\
\hline IPA 11 & $0.436 \mathrm{c}$ & $9.56 \mathrm{~b}$ & $0.017 \mathrm{~b}$ \\
\hline $\mathrm{CV}(\%)$ & 2.57 & 18.45 & 4.67 \\
\hline
\end{tabular}


average number of leaves. The Serena F1 hybrid had the greatest average number of leaves per plant, followed by the others, Mata Hari, Lambada, Fortaleza F1, Predileta F1 e Cronus F1, which did not differ from each another. According to Resende et al. (2007), the higher leaf-area index seen as a result of the greater height of hybrid plants, indicates a consequently higher rate of photosynthesis, suggesting the production of more photoassimilates to be stored as reserves in the bulb.

Five of the eight hybrids had a yield of over $70 \mathrm{t} \mathrm{ha}^{-1}$. The Serena F1 hybrid was the most productive $(78,670$ $\mathrm{kg} \mathrm{ha}^{-1}$ ) and did not significantly differ from the Mata Hari cultivar, which produced 76,290 $\mathrm{kg} \mathrm{ha}^{-1}$ (Table 2). Despite achieving high yields as a result of the level of technology adopted, these values are consistent with those observed by Faria et al. (2012) and Baier et al. (2009), who obtained yields of $75.23 \mathrm{t} \mathrm{ha}^{-1}$ with the 2572 hybrid and up to $92.20 \mathrm{t} \mathrm{ha}^{-1}$ with the Buccaneer hybrid under high population density. The control under test, IPA 11, showed a lower performance for productivity $\left(62,250 \mathrm{~kg} \mathrm{ha}^{-1}\right)$. Nevertheless, these values are in accordance with the high levels of productivity that were observed in cultivar IPA 11 by Souza and Resende (2003) in regions around Mossoró, RN and Petrolina, in the state of Pernambuco, with yields to the order of 45.89 and $48.25 \mathrm{t} \mathrm{ha}^{-1}$ respectively. However, the present work surpassed values reported by Souza et al. (2008), who assert that the cultivars of IPA, Alfa San Francisco and Alfa Tropical series should be recommended for the northeast.

The average bulb weight of the hybrids ranged from 0.093 to $0.123 \mathrm{~kg}$; the noteworthy hybrids being Serena F1 and Mata Hari, which had significantly higher values of 0.123 and $0.122 \mathrm{~kg}$ respectively (Table 2). Araújo et al. (2004) observed similar values, ranging from 100 to $136 \mathrm{~g}$, with no significant differences. These values are consistent with those observed by Resende et al. (2007), in the south-central region of the state of Paraná, who reported values ranging from 52.13 to $159 \mathrm{~g}$, notably from the Buccaneer hybrid. Faria et al. (2012), working in the south-central region of Paraná, noted values for hybrids and strains ranging from 92.0 to $178.5 \mathrm{~g}$ and 40.3 to $187.29 \mathrm{~g}$. These are much higher however than those reported by Resende, Chagas and Pereira (2003), who saw variations in average weight from 45.99 to $97.69 \mathrm{~g}$ for the cultivars Chata Roxa and Granex respectively, grown in the south of the state of Minas Gerais. For the survival rate of the plants the percentages were adequate, ranging from 90.8 to 98.4 (Table 2), the hybrid Serena F1 standing out with significantly higher values, but not that different from Predileta F1.
The genotypes were divided into three groups according to the waxiness of their leaves, however the differences between hybrids were intermediate (Table 2). This characteristic also showed a median coefficient of variation, so the methodology adopted in this study was therefore not sufficient to distinguish the plants under test. These values were also seen by Faria et al. (2012) where hybrids and strains were studied for leaf waxiness, however the differences between and within the groups were not sufficient for the genotypes to be distinguished. This factor is very important for agricultural activities, because the more waxy the surface of the leaf or branch, the larger the number of droplets formed, the smaller the area for wetting, the greater the possibility of injury and the less the efficiency when spraying for nutrition or for the control of pests and disease. Garlic, onion, cabbage and cauliflower, are examples of crops with highly waxy leaves and which therefore require a surfactant to be used together with the spraying solution.

For cultivation cycle, the IPA 11 control hybrid was classified in the group of more tardy cultivars (Table 2). But these are far superior to those reported by Ramos, Deon and Aragon (2005), who observed a cycle of 124 days for IPA 11. The earliest hybrid was Serena F1 (140.44 days), showing no differences from Mata Hari. The strains had an average cycle of 150.07 days, and despite there being differences between them, they are of a few days only. The verified cycles were shorter in the genotypes under test due to higher temperatures in the growing season, typical of the Baraúna region, compared to other onion-producing regions. However, most of the genotypes tested were earlier than the control, due to coming from progenies derived from so-called 'super-early' germplasm. These results were different from those reported by Faria et al. (2012), where the cycle for the tested genotypes was prolonged, probably due to the lower temperatures of the growing season, typical of the region of Guarapuava. A reduction in the cycle is an important characteristic that can be taken into consideration in breeding programs because the earlier the crop, the better the use made of the land, thereby increasing the profitability.

Among the hybrids tested, Serena F1 showed the highest percentage $(82.67 \%)$ of bulbs in Caixa (class) 3, considered ideal for marketing. It was seen that for the classes Birita and Caixa 4, considered rejects, the hybrids Serena F1 and Luana had the lowest percentage at $0.53 \%$ and $1.62 \%$ respectively (Table 3 ). The control, IPA 11 , had a high percentage of bulbs considered rejects $(3.02 \%$ Birita and $15.91 \%$ Caixa 4), also being considered as below standard according to the classification of the Ministry of Agriculture, Livestock and Supply - MAPA, and agreeing with the findings of Duarte et al. (2003) for the onions Vale Ouro IPA 11 and Franciscana IPA 10 
Table 2 - Productivity, average bulb weight, survival rate, leaf waxiness and cycle, for onion varieties grown in the semi-arid region in Baraúna, $\mathrm{RN}, 2012$

\begin{tabular}{lccccc}
\hline Cultivar & Productivity $\left(\mathrm{kg} \mathrm{ha}^{-1}\right)$ & Average bulb weight $(\mathrm{kg})$ & Survival rate (\%) & Leaf waxiness (\%) & Cycle (days) \\
\hline Cronus F1 & $73,770 \mathrm{~b}$ & $0.116 \mathrm{~b}$ & $97.3 \mathrm{~b}$ & $3.31 \mathrm{~b}$ & $152.46 \mathrm{~b}$ \\
Predileta F1 & $71,700 \mathrm{~b}$ & $0.112 \mathrm{~b}$ & $98.1 \mathrm{a}$ & $3.56 \mathrm{~b}$ & $149.32 \mathrm{~b}$ \\
Serena F1 & $78,670 \mathrm{a}$ & $0.123 \mathrm{a}$ & $98.4 \mathrm{a}$ & $4.22 \mathrm{a}$ & $140.44 \mathrm{a}$ \\
Fortaleza F1 & $75,020 \mathrm{~b}$ & $0.118 \mathrm{~b}$ & $97.5 \mathrm{~b}$ & $3.31 \mathrm{~b}$ & $152.46 \mathrm{~b}$ \\
Don Victor & $58,750 \mathrm{~d}$ & $0.093 \mathrm{~d}$ & $97.1 \mathrm{~b}$ & $2.40 \mathrm{c}$ & $154.14 \mathrm{~b}$ \\
Luana & $60,150 \mathrm{c}$ & $0.098 \mathrm{~d}$ & $94.2 \mathrm{c}$ & $2.40 \mathrm{c}$ & $154.14 \mathrm{~b}$ \\
Mata Hari & $76,290 \mathrm{a}$ & $0.122 \mathrm{a}$ & $96.2 \mathrm{c}$ & $3.31 \mathrm{~b}$ & $140.44 \mathrm{a}$ \\
Lambada & $63,920 \mathrm{c}$ & $0.102 \mathrm{c}$ & $95.7 \mathrm{c}$ & $3.56 \mathrm{~b}$ & $149.32 \mathrm{~b}$ \\
IPA 11 & $62,250 \mathrm{c}$ & $0.105 \mathrm{c}$ & $90.8 \mathrm{~d}$ & $2.40 \mathrm{c}$ & $157.87 \mathrm{c}$ \\
\hline CV $(\%)$ & 3.56 & 3.71 & 4.67 & 17.62 & 0.97 \\
\hline
\end{tabular}

* Averages followed by the same letter do not differ statistically by Skott-Knott test $(\alpha=0.05)$

Table 3 - Percentage of onion bulbs obtained in accordance with the commercial class as determined by CEASA (Centres for supply in Ceará) 2012

\begin{tabular}{lcccc}
\hline \multirow{2}{*}{ Cultivar } & \multicolumn{4}{c}{ Commercial class \% bulbs } \\
\cline { 2 - 5 } & Birita & Caixa 2 & Caixa 3 & Caixa 4 \\
\hline Cronus F1 & 4.72 & 15.74 & 74.89 & 4.65 \\
Predileta F1 & 4.14 & 10.15 & 75.45 & 10.26 \\
Serena F1 & 0.53 & 10.84 & 82.67 & 5.96 \\
Fortaleza F1 & 3.78 & 12.87 & 76.93 & 6.42 \\
Don Victor & 7.12 & 18.65 & 70.43 & 3.8 \\
Luana & 4.35 & 20.51 & 73.52 & 1.62 \\
Mata Hari & 3.71 & 5.69 & 79.33 & 11.27 \\
Lambada & 6.78 & 10.88 & 75.67 & 6.67 \\
IPA 11 & 3.02 & 8.42 & 72.65 & 15.91 \\
\hline
\end{tabular}

(12 e 7\%) and of Souza et al. (2008) for the cultivars, Alfa São Francisco e Vale Ouro IPA 11 (33.15 e 14.45\%). It should be emphasized that obtaining superior-class onions results in better commercial return and a greater acceptance in the Brazilian market, and this is considered by Reghin et al. (2006) to be an indicator of the high quality of the production achieved.

In the short term, the use of these hybrids can certainly help to change the outlook of the onion crop in the state of Rio Grande do Norte and in other regions having similar climates to the semi-arid climate of that state, increasing productivity, quality and profitability for producers, and demonstrating that the cultivars can be viable for cultivation in the area.

\section{CONCLUSIONS}

The onion hybrids Serena F1 and Mata Hari are recommended for the semi-arid north eastern region due to their high productivity, early cycle and better bulb classification. In turn, the IPA 11 variety was considered of a lower standard in relation to the hybrids.

\section{REFERENCES}

AMARO FILHO, J. Contribución al estudio del clima del Rio Grande do Norte. 1991. 311 p. Tese (Doutorado em Edafologia e Climatologia) - Universidade Politécnica de Madrid. Madrid, 1991. 
ARAÚJO, J. F. et al. Avaliação de genótipos em cultivo orgânico. Horticultura Brasileira, v. 22, n. 2, p. 3, 2004. Suplemento.

BAIER, J. E. et al. Produtividade e rendimento comercial de bulbos de cebola em função da densidade de cultivo. Ciência e Agrotecnologia, v. 33, n. 2, p. 496-501, 2009.

BANDEIRA, G. R. L. et al. Desempenho agronômico de cultivares de cebola sob diferentes manejos de irrigação no submédio São Francisco. Irriga, v. 18, n. 1, p.73-84, 2013.

DUARTE, R. L. R. et al. Produtividade de cultivares de cebola no Semi-árido piauiense. Horticultura Brasileira, v. 21, n. 1, p. 34-36, 2003.

EMPRESA BRASILEIRA DE PESQUISA AGROPECUÁRIA. Sistema Brasileiro de Classificação de Solos. Rio de Janeiro: Centro Nacional de Pesquisa de Solos, 2006. 412 p.

FOOD AND AGRICULTURE ORGANIZATION. Agricultural production, primary crops. Disponível em: < www.fao.org >. Acesso em: 24 abr. 2013.

FARIA, M. V. et al. Desempenho agronômico e heterose de genótipos de cebola. Horticultura Brasileira, v. 30, n. 2, p. $220-225,2012$.

FINGER, F. L.; CASALI, V. W. D. Colheita, cura e armazenamento da cebola. Informe Agropecuário, v. 23, n. 218, p. $93-98,2002$.

GRANGEIRO, L. C. et al. Características qualitativas de genótipos de cebola. Ciências e Agrotecnologia, v. 32, n. 4, p. 1087-1091, 2008

INSTITUTOBRASILEIRODE GEOGRAFIAEESTATÍSTICA. Estatísticas da produção agrícola. 2012. Disponível em: < http://www.ibge.gov.br >. Acesso em: 24 abr. 2013.

LONGO, A. E. Micropropagação de alho e ginogênese in vitro de cebola. 2009. 130 p. Dissertação (Mestrado em
Genética, Melhoramento Vegetal e Biotecnologia), Instituto Agronômico de Campinas, Campinas, 2009.

MOTA, J. C. A. Caracterização física, química e mineralógica, como suporte para o manejo, dos principais solos explorados com melão na Chapada do Apodi - RN. 2004. 96p.. Dissertação (Mestrado em Agronomia/Solos e Nutrição de Plantas), Universidade Federal do Ceará, 2004.

RAMOS, P. S. R.; DEON, J. S.; ARAGÃO, C. A. Desempenho e pungência de genótipos de cebola na região do Submédio São Francisco. Horticultura Brasileira, v. 23, n. 2, p. 1-4, 2005. Suplemento.

REGHIN, M. Y. et al. Produção de cebola sobre palhada a partir de mudas obtidas em bandejas com diferentes números de células. Horticultura Brasileira, v. 24, n. 4, p. 414-420, 2006.

RESENDE, G. M.; CHAGAS, S. J. R.; PEREIRA, L. Características produtivas de cultivares de cebola no Sul de Minas Gerais. Horticultura Brasileira, v. 21, n. 4, p. 722-725, 2003.

RESENDE, V. T. J. et al. Desempenho produtivo de cultivares de cebola em Guarapuava, Paraná Ambiência - Revista do Setor de Ciências Agrárias e Ambientais, v. 3 n. 2, p. 193-199, 2007.

SOUZA, J. L.; RESENDE, P. Manual de horticultura orgânica. Viçosa: Aprenda Fácil, 2003. 564 p.

SOUZA, J. O. et al. Avaliação de genótipos de cebola no Semi-Árido Nordestino. Horticultura Brasileira, v. 26, n. 1, p. 97-101, 2008.

VARGAS, P. F.; BRAZ, L. T.; MAY, A. Produtividade de cultivares de cebola em função do número de mudas por célula de bandeja e espaçamento entre covas. Horticultura Brasileira, v. 25, n. 2, p. 241-245, 2007.

VILELA, N. J. et al.. Desafios e oportunidades para o agronegócio de cebola no Brasil. Horticultura Brasileira, v. 23 , n. 4 , p. 1029-1033, 2005. 